\title{
Yellow band disease compromises the reproductive output of the Caribbean reef-building coral Montastraea faveolata (Anthozoa, Scleractinia)
}

\author{
Ernesto Weil*, Aldo Cróquer, Isabel Urreiztieta \\ Department of Marine Sciences, University of Puerto Rico, PO Box 3208, Lajas 00667, Puerto Rico
}

\begin{abstract}
Sexual reproduction is critical to coral population dynamics and the long-term regeneration of coral reefs. Bleaching, disease, and/or anthropogenic-induced tissue/colony loss reduce reproductive output. This is the first attempt to explore the effect of a biotic disease on the reproduction of scleractinian corals. The study aimed to assess the effect of yellow band disease (YBD) on the reproduction of the important Caribbean reef-builder Montastraea faveolata. Tissue samples were collected from diseased, transition, and healthy-looking areas in each of 5 infected colonies and from 5 healthy controls in southwest Puerto Rico. The effect of disease-induced mortality was assessed by collecting samples from the edge and center of surviving small and large, healthy-looking tissue patches from large, previously infected tagged colonies. Fecundity was significantly lower in disease lesions compared to transition and healthy-looking tissues and the controls (99\% fewer eggs). Fecundity in transition areas was significantly lower $(50 \%)$ than in healthy-looking tissues in diseased colonies, which had $23 \%$ lower fecundity than control tissues. Although this fecundity drop was not statistically significant, it could indicate a systemic effect of YBD across the colony. Large and small patches had 64 and $84 \%$ fewer eggs than controls, respectively, and edge polyps had $97 \%$ fewer eggs than those in central control areas. Field observations of the spawning behavior of each tissue area corroborated the histological results. Our results indicate that YBD significantly compromises the reproductive output of $M$. faveolata, potentially reducing the fitness and consequently, the recovery of this important reef-building species on Caribbean coral reefs.
\end{abstract}

KEY WORDS: Coral diseases $\cdot$ Yellow band disease $\cdot$ Coral reproduction $\cdot$ Fecundity $\cdot$ Montastraea faveolata

\section{INTRODUCTION}

Reproductive strategies, dispersion, and recruitment are key processes in the life history and evolution of wildlife species because they are strongly subjected to natural selection (Knowlton et al. 1992, Hilbish 1996, Saccheri \& Hanski 2006). Individual fitness can be defined as the average product of fecundity (e.g. number of offspring, eggs, gametes) and survivorship, both representing the net reproductive effort of an individual (Metz et al. 1992). In corals, pattern and mode of reproduction, fertilization success, larval dispersal, recruitment, and juvenile survivorship are important components of fitness (Szmant 1986, Edmunds 2005, Van
Oppen et al. 2002, Vermeij et al. 2003, Vermeij 2006) Each of these processes is critical to coral population dynamics and the regeneration of coral reef communities (Harrison \& Wallace 1990, Vermeij 2005). Recurrent recruitment failure and low reproductive output in corals have been highlighted as major reasons explaining why reefs are not recovering from recent community phase-shift events (Hughes \& Connell 1999, Hughes \& Tanner 2000).

At present, coral fitness is influenced by the combination of natural (predation, resource competition, environmental constraints, parasitism, disease) and anthropogenic (e.g. eutrophication, chemical pollution, habitat degradation, climate change) factors, 
which could reduce fecundity and/or decrease offspring survivorship. Biotic and abiotic diseases affect wildlife populations by reducing population sizes and genetic diversity. Infectious diseases have a strong negative influence on individual fitness of affected hosts, thereby representing a strong selective force for rapid pathogen and/or host evolution (Daszak et al. 2000, Altizer et al. 2003, Deredec \& Courchamp 2003). Parasites may affect fecundity by altering host physiology, host energy budgets, reproductive behavior of mates, and/or sex ratio of the affected populations (Gulland 1995, Alker et al. 2004). Several factors including competition, temperature, light, depth (Kojis \& Quinn 1984, Tanner 1997, Mendes \& Woodley 2002a), eutrophication (Ward \& Harrison 1997, 2000, Bassin \& Sammarco 2003, Bongiorni et al. 2003), mechanical stress (Ward 1995), sedimentation (Harrison \& Wallace 1990), oil pollution (Guzmán \& Holst 1993), UV light (Torres et al. 2008), and bleaching (Szmant \& Gassman 1990, Ward et al. 2000, Mendes \& Woodley 2002b) have been shown to affect the reproduction and fitness of Caribbean, Indo-Pacific, and Red Sea corals.

During the past 3 decades, coral diseases have significantly influenced coral reef ecosystems around the world (Willis et al. 2004, Sutherland et al. 2004, Weil et al. 2006, Harvell et al. 2007, Carpenter et al. 2008). Several epizootic events have caused extensive coral tissue mortality, significantly reducing live coral cover and biomass, with some important reef-building species suffering up to $95 \%$ mortality across their geographic range, particularly in the Caribbean region (Gladfelter 1982, Lessios et al. 1984, Aronson \& Precht 2001, Bruckner \& Bruckner 2006, Rogers \& Miller 2006).

Most studies of coral diseases have focused on determining the effects they have at population and community levels (Nugues 2002, Borger \& Steiner 2005, Bruckner \& Bruckner 2006, Miller et al. 2006). Besides 2 studies on the effects of the fungal disease aspergillosis on the reproduction of the Caribbean sea-fan Gorgonia ventalina (Petes et al. 2003, Flynn \& Weil in press), nothing is known about the effect of diseases on the reproductive biology and output of scleractinian corals, an important gap in information since diseases have become a major player in reef decline and sexual reproduction is essential for population and reef recovery.

Yellow band disease (YBD) is a widespread coral disease (Weil et al. 2002, Weil \& Cróquer 2009) that primarily affects the main Caribbean reef-builders Montastraea faveolata, M. annularis, and M. franksi. This disease seems to mainly affect the zooxanthellae and is closely associated with Vibrio bacteria (Cervino et al. 2001, 2004a, 2008, Weil et al. in press).

The mechanisms of coral tissue mortality, infection, and pathogen transmission, as well as vector(s) and reservoir(s), are still not known (but see Cervino et al. 2008). Laboratory and field experiments have shown that the pathogen(s) is apparently not transmitted through the water or by direct contact of infected and healthy fragments/colonies (Cervino et al. 2004, Bruckner \& Bruckner 2006, E. Weil \& J. F. Bruno unpubl. data). The disease typically produces an initial round, pale yellowish blotch surrounded by healthylooking tissues in central areas of the colony, or yellowish-pale bands at the colony edge or around depressed areas with sediment accumulation or algal growth (Fig. 1) (Santavy et al. 1999, Gil-Agudelo et al. 2004). The central areas of the blotches eventually die, leaving a crescent shape with the characteristic yellow band that varies in width ( 1 to $5 \mathrm{~cm}_{\text {; Fig. }} 1 \mathrm{~b}$ ). As the disease progresses, the crescent band expands in all directions. Some large colonies develop multiple lesions that usually coalesce (Fig. 1b), often resulting in nearly complete or complete colony mortality (Fig. 1e). The virulence of YBD (rate of tissue mortality) is highly variable, from a few millimeters to several centimeters per month (Bruckner \& Bruckner 2006, Harvell et al. 2009) and could be affected by nutrient concentrations (Bruno et al. 2003), temperature (Cervino et al. 2004, Harvell et al. 2009), and other factors.

Before looking into how disease affects the reproductive biology (different stages and/or mechanisms), it is necessary to demonstrate that it does have an effect on the reproductive output. This study presents the first attempt to assess the effect of a highly damaging and widespread disease on the reproductive output (fecundity) of one of the most important reef-building species in the wider Caribbean, the star coral Montastraea faveolata.

\section{MATERIALS AND METHODS}

Study area and sample collection. The study was carried out in Turrumote reef $\left(17^{\circ} 56.1^{\prime} \mathrm{N}\right.$ and $67^{\circ} 01.1^{\prime} \mathrm{W}$ ), a mid-shelf fringing reef located $2 \mathrm{~km}$ off $\mathrm{La}$ Parguera, on the southwest coast of Puerto Rico. As in many Caribbean reefs, the Turrumote coral community is dominated by large colonies of Montastraea faveolata between 3 and $15 \mathrm{~m}$ that have been persistently affected by YBD since the late 1990s. Disease prevalence increased from $1.0 \%$ in 1999 to $55 \%$ in the summer of 2007 (E. Weil unpubl. data). To assess fecundity with high confidence by the identification and quantification of mature eggs, tissue samples were collected during the first week of August 2005, 1 wk before the expected spawning event of $M$. faveolata for that year.

Experimental design, sample collection, and processing. To assess the effect of YBD on the fecundity at different dynamic stages, we tested the overall effect 

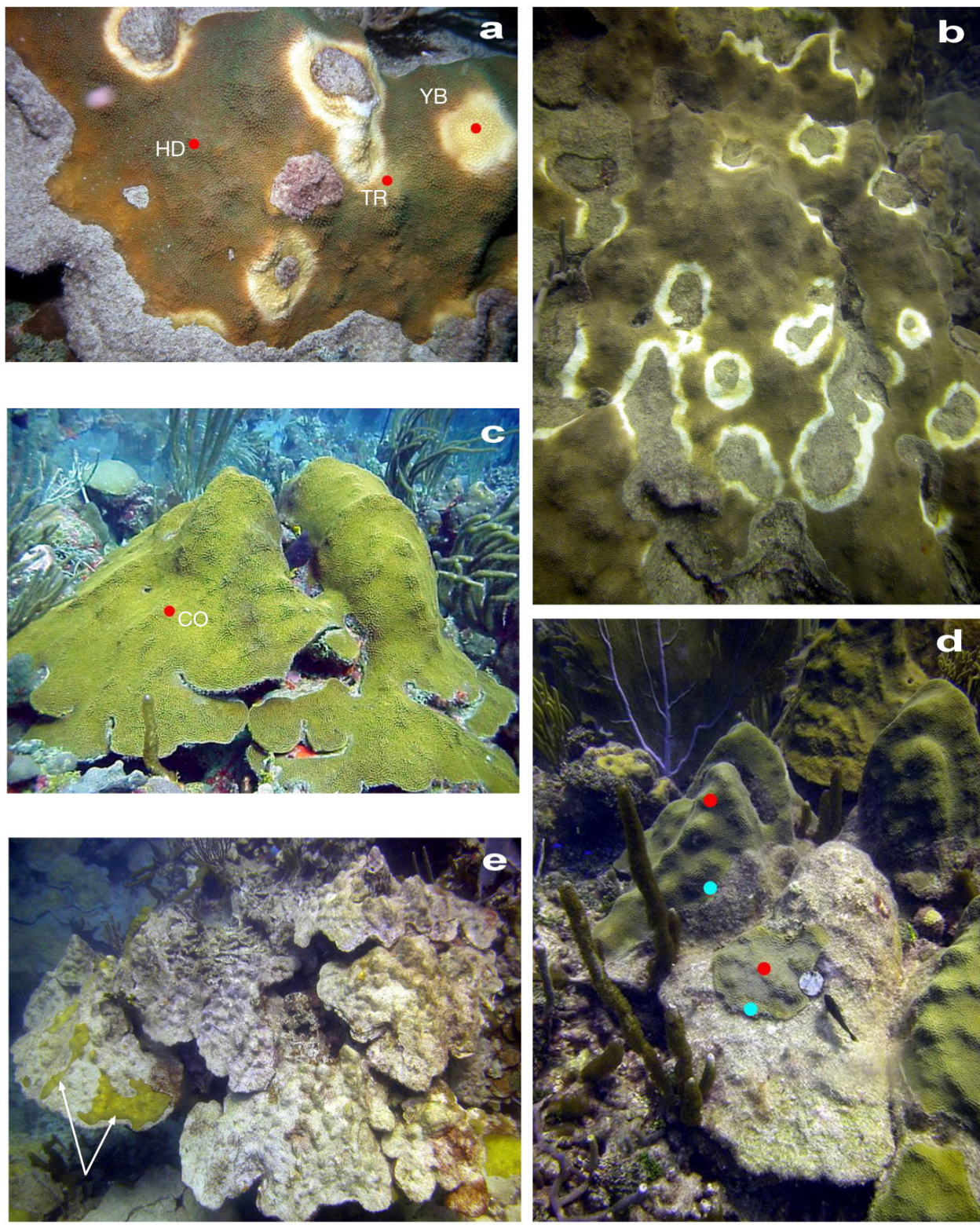

Fig. 1. Montastraea faveolata. (a) General initial YBD-infection stages (pale blotches), advancing active crescent lesions, and the location of tissue samples (red dots - HD: healthy-looking tissues in infected colonies; TR: transition tissues; YB: YBD-infected tissues); (b) large colony with multiple coalescing lesions; (c) exemplary location of tissue sample (red dot) in a healthy control (CO) colony; (d,e) old, large, tagged colony previously infected with YBD showing (d) collection locations for edge (blue dots) and center (red dots) samples of healthy-looking surviving patches and (e) healthy-looking surviving patches (arrows) of various sizes

of the disease on the fecundity of Montastraea faveolata in corals with active disease lesions (Expt 1) and then, in surviving patches of tagged colonies that were affected by YBD in previous years and had not shown disease signs for at least $1 \mathrm{yr}$ by the sampling date (Expt 2). In Expt 1, overall fecundity (total number of eggs counted in transversal polyp preparations) was compared among 4 treatments from 5 YBD-infected colonies with similar diameter (1.5 to $2.0 \mathrm{~m})$, located at the same depth $(10 \mathrm{~m})$, and separated by at least $5 \mathrm{~m}$ to avoid clones (ramets). A single sample was collected from each of the following tissue treatments in each of the 5 colonies (independent replicates): (1) control (CO) from healthy-looking colonies with no signs of any disease or other stress, (2) healthy-looking areas (HD) in the YBD-infected colonies, (3) transition area (TR) (2 to $3 \mathrm{~cm}$ from YBD lesion), and (4) diseaseinfected areas (YB) away from colony edges (Fig. 1a,c).

In Expt 2, we tested the effect of mortality caused by multiple YBD infections on the fecundity of recovered 
Montastraea faveolata. Two tissue samples (one at the center and one at the edge) were collected from surviving tissue patches of different sizes (small [S]: 35 to $150 \mathrm{~cm}^{2}$ and large [L]: 200 to $1000 \mathrm{~cm}^{2}$ ) from 5 large, tagged colonies (replicates; Fig. 1d,e) that have been monitored for several years. Tissue patches resulted from partial mortality produced by multiple YBD lesions that affected these colonies since 2000 until the disease arrested. Continuous monitoring indicated that patches have not had any disease signs for several years. Tissue patches were separated by bare or algaeovergrown skeletons. The projected surface area $(A)$ was measured with a tape before collecting and then approximated to an ellipse $\left(A=\pi \times\left[d_{1} / 2\right] \times\left[d_{2} / 2\right]\right.$ where $d_{1}$ and $d_{2}$ are the major and minor axes, respectively) as suggested by Nugues (2002). Control samples were the same as for Expt 1 to avoid damaging more colonies.

Tissue samples were carefully collected by coring or by cutting areas no larger than $5 \mathrm{~cm}$ in diameter with a hammer and chisel. Cores/pieces were put in labeled plastic bags and immediately taken to the laboratory and fixed for histological preparation and analysis. Histological preparation followed well-tested protocols (Szmant 1986, Szmant \& Gassman 1990): (1) fixation with Zenker-formaline (10\%) solution for $24 \mathrm{~h}$, (2) rinsing with tap water for $24 \mathrm{~h}$, (3) decalcification with multiple changes of $10 \%$ hydrochloric acid and testing for $\mathrm{CaCO}_{3}$ residuals with the ammonium oxalate test, (4) preservation in $70 \%$ ethanol, (5) dehydratation with ethanol and isopropanol solutions, (6) embedding in paraffin at $60^{\circ} \mathrm{C},(7)$ sectioning with a rotary microtome (Leitz 1512) and (8) staining according to Heidenhain's aniline-blue method.

For each treatment, 5 histological tissue sections (one from each independent colony) were observed under the microscope to check and count the number of eggs. Average fecundity was estimated by counting the eggs present in the transverse section of the 12 polyp mesenteries in each of 5 non-contiguous polyps haphazardly selected from the microscope field of view projected on a computer screen through Sigma-Scan (SPSS) image analysis software. Results from histological analysis were complemented with direct spawning observations in the field. We monitored the spawning behavior of Montastraea faveolata colonies from which tissue samples were collected as well as from several other healthy and diseased colonies in the same reef, paying close attention to the diseased, transition, and healthylooking areas within diseased colonies, control colonies, and the different sized surviving patches.

Data analysis. A variance component analysis was performed to estimate the total variance explained by treatments, mesenteries within polyps, polyps within colonies, and colonies. In Expt 1, fecundity was com- pared among compartments/treatments (CO, HD, TR, and YB) with a 1-way analysis of variance (ANOVA). Data were transformed $(\sqrt{ } y+0.5)$ to fulfill ANOVA assumptions (Sokal \& Rohlf 1995). To assess the effect of size reduction by partial mortality (patch size $=\mathrm{S}$ and L) and tissue location (center and edge) on fecundity, a nested ANOVA (location nested within patch size) was done. A Bonferroni test was performed for post hoc comparisons in both experiments. We could not perform an analysis of covariance (ANCOVA) because the slopes of pooled treatments and the covariate (patch size) were not homogenous even after data transformation. Instead, a simple linear regression between the total number of eggs per polyp and per mesentery and the size of each patch (i.e. surface area) was performed. To test if the number of gravid mesenteries within the polyps was independent of treatments (i.e. tissue compartments, patch size, and position), a G-test for fixed counts was used (Sokal \& Rohlf 1995).

\section{RESULTS}

Polyps and mesenteries from YB, HD, and TR tissues had significantly fewer eggs than healthy tissues in $\mathrm{CO}$ colonies. Close to $73 \%$ of the total variance of the mean number of eggs was due to variability among tissue treatments, $20 \%$ to experimental error, and 3.8, 2.1 , and $1.1 \%$ to variation among colonies, polyps, and mesenteries, respectively. Variance values resulted in part from the low number of replicates. A 1-way ANOVA indicated a significant reduction (99\%) in the mean number of eggs within the mesenteries $(F=4.6$, $\mathrm{df}=3, \mathrm{p}<0.05)$ and polyps $(F=22.9, \mathrm{df}=3, \mathrm{p}<0.05)$ in YB tissues compared to CO tissues (Fig. 2). YB tissues had $0.02 \pm 0.2$ eggs mesentery ${ }^{-1}($ mean $\pm \mathrm{SE}, \mathrm{n}=60$ ) and $0.3 \pm 2.4$ eggs polyp ${ }^{-1}(n=5)$, whereas in the controls, the mean number of eggs per mesentery and per polyp was $2.3 \pm 0.2$ and $23.7 \pm 2.4$, respectively. Likewise, there was a significant reduction (50\%) in the total number of eggs found within mesenteries and polyps in TR tissues compared to CO tissues (Fig. 2). HD tissues had $27 \%$ lower fecundity compared to $\mathrm{CO}$, but $24 \%$ higher fecundity than TR tissues, although neither of these differences was significant (Fig. 2). Furthermore, there was a strong dependency ( $G=$ 529.8, df $=3, \mathrm{p}<0.05$ ) between the total number of mesenteries bearing eggs and types of tissues (CO, HD, TR, and YB; Table 1). These results showed an important trend indicating the potential systemic effect of YBD on infected colonies of Montastraea faveolata, which increases the overall colony effect of this disease.

Results from Expt 2 showed that the size of the surviving patches $(F=40.2, \mathrm{df}=2, \mathrm{p}<0.05$; nested 

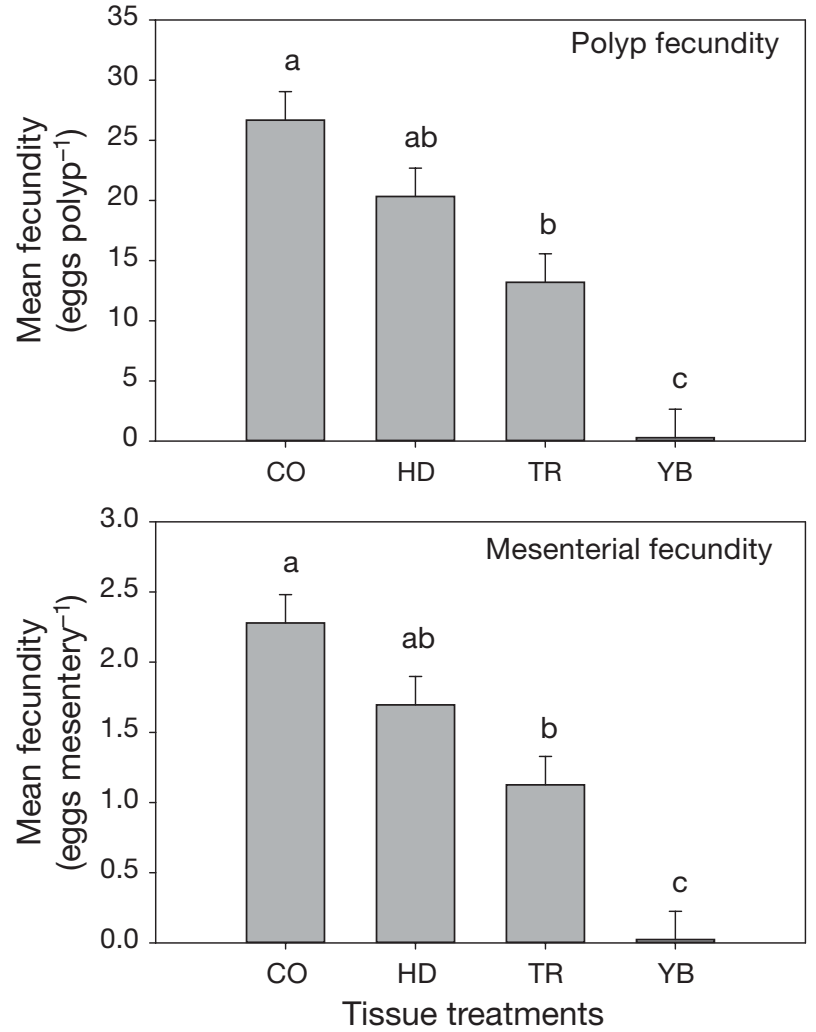

Fig. 2. Montastraea faveolata. Mean fecundity (SE) and 95\% confidence intervals in polyps and mesenteries in each of the tissue treatments. Different letters above bars indicate significant differences (ANOVA, $\mathrm{p}<0.05)$. CO: controls; HD: healthy-looking tissue in diseased colony; TR: transition tissues (areas in the border of the YBD lesion); YB: diseaseinfected tissue (pale-yellowish) in sampled colonies

ANOVA $)$ and the location of the sample $(F=25.4, \mathrm{df}=2$, $\mathrm{p}<0.05$ ) had significant effects on fecundity (mean number of eggs per mesentery and per polyp) in the patches. Large and small tissue patches had $64 \%$ and $84 \%$ reduction in fecundity, respectively (fewer eggs polyp $^{-1}$ ) compared to controls (Fig. 3). Mesentery and

Table 1. Montastraea faveolata. G-test analysis showing the total number of gravid (with eggs) and non-gravid (no eggs) mesenteries in the different tissue treatments: CO: healthy control colonies; HD: healthy-looking tissues in infected colonies; TR: transition tissues; YB: YBD-infected colonies ( $\mathrm{n}=12$ mesenteries $\times 5$ polyps $\times 5$ colonies)

\begin{tabular}{|lccc|}
\hline Tissue compartment & Gravid & Non-gravid & Total \\
\hline CO & 298 & 2 & 300 \\
HD & 263 & 37 & 300 \\
TR & 197 & 103 & 300 \\
YB & 69 & 231 & 300 \\
Total & 827 & 373 & 1200 \\
\multicolumn{4}{c}{$G=529.8, \mathrm{df}=3, \mathrm{p}<0.05$} \\
\hline
\end{tabular}

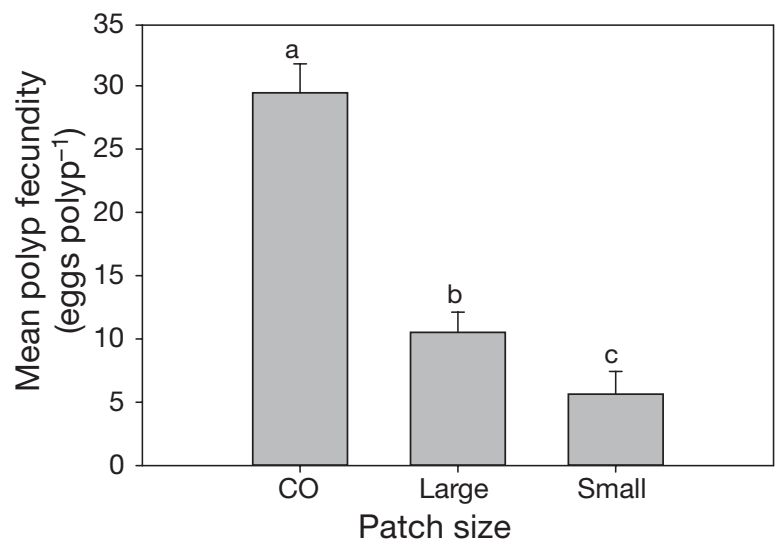

Fig. 3. Montastraea faveolata. Mean and 95\% confidence intervals of polyp fecundity (eggs polyp ${ }^{-1}$ ) in control tissues (CO) and large (200-1000 $\left.\mathrm{cm}^{2}\right)$ and small $\left(35-150 \mathrm{~cm}^{2}\right)$ patches of surviving tissue. Different letters above bars indicate significant differences (nested ANOVA, $\mathrm{p}<0.05$ )

polyp fecundity and patch size covaried significantly and positively $\left(\mathrm{r}^{2}=0.55, \mathrm{p}=0.01\right.$ and $\mathrm{r}^{2}=0.54, \mathrm{p}=0.01$, respectively), such that larger patches had higher fecundity (Fig. 4). Fecundity at the center and edge of small patches and the edge of large patches was 2 orders of magnitude lower $(0.08 \pm 0.03)$ than controls
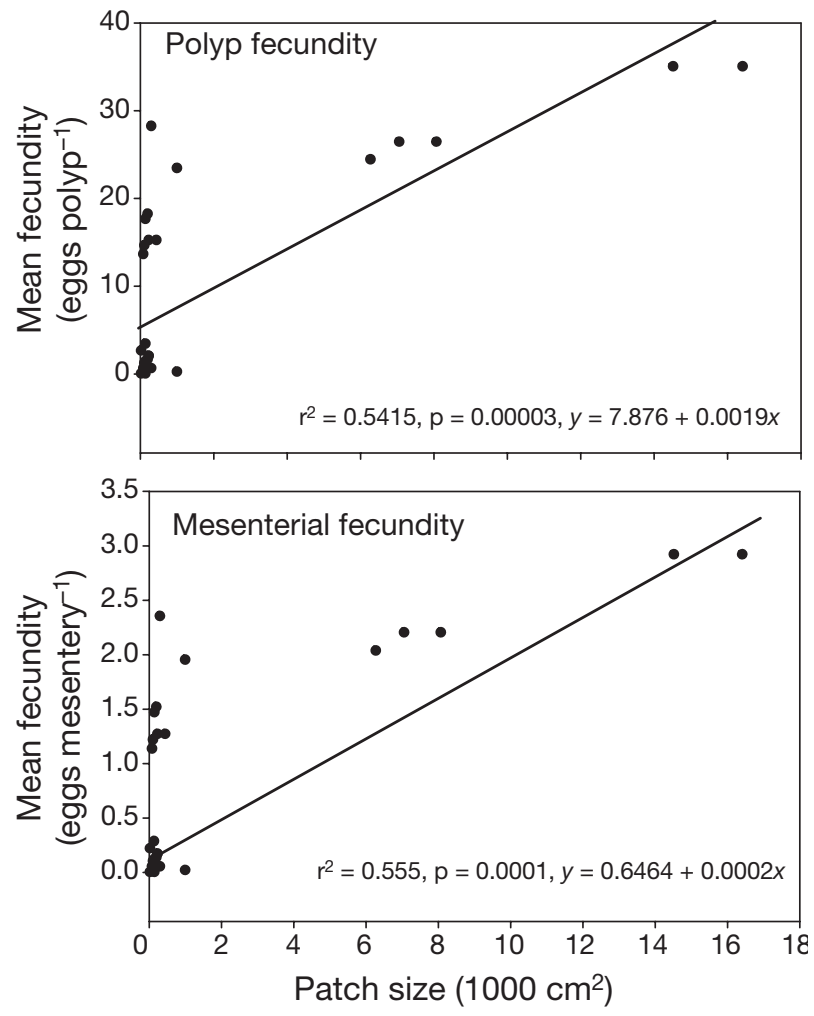

Fig. 4. Montastraea faveolata. Regression analysis of fecundity (number of eggs) in polyps and mesenteries and the area of living tissue patches in colonies previously affected by YBD 
$(2.5 \pm 0.19)$ with $97 \%$ fewer eggs $(0.96 \pm 0.4)$ than control colonies $(29.4 \pm 2.3)$, and it was $50 \%$ lower $(1.3 \pm$ 0.2 ) at the center areas compared to controls, indicating that sexual reproduction was still affected even in

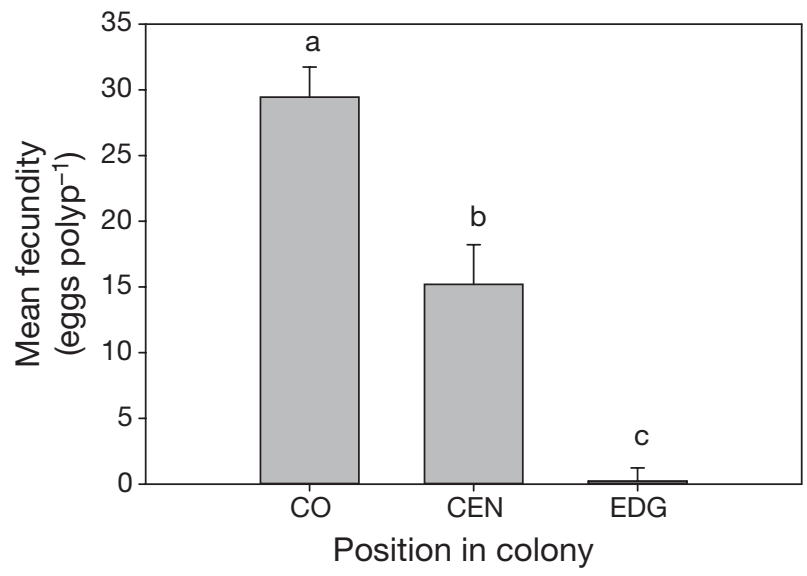

Fig. 5. Montastraea faveolata. Mean and 95\% confidence intervals of polyp fecundity (number of eggs polyp ${ }^{-1}$ ) in tissues from central areas of control colonies (CO), central areas of large patches (CEN), and edge areas (EDG). Different letters above bars indicate significant differences (ANOVA, $\mathrm{p}<0.05)$

Table 2. Montastraea faveolata. G-test analysis showing the total number of gravid (with eggs) and non-gravid (no eggs) mesenteries in large and small, surviving tissue patches from healthy-looking patches from tagged colonies previously infected with YBD but that had no disease signs in last $2 \mathrm{yr}$ before sampling $(n=12$ mesenteries $\times 5$ polyps $\times 5$ colonies $\times$ 2 patch sizes)

\begin{tabular}{|lccc|}
\hline Size & Gravid & Non-gravid & Total \\
\hline Control (whole colony) & 298 & 2 & 300 \\
Small & 277 & 323 & 600 \\
Large & 201 & 399 & 600 \\
Total & 776 & 724 & 1500 \\
& \multicolumn{3}{c}{$G=3164.8, \mathrm{df}=2, \mathrm{p}<0.05$} \\
\hline
\end{tabular}

Table 3. Montastraea faveolata. G-test analysis showing the total number of gravid (with eggs) and non-gravid (no eggs) mesenteries in control, patch center, and patch edge tissues from previously tagged, infected colonies that had no disease signs in the previous $2 \mathrm{yr}(\mathrm{n}=12$ mesenteries $\times 5$ polyps $\times$ 5 colonies $\times 2$ positions)

\begin{tabular}{|lccc|}
\hline Position & Gravid & Non-gravid & Total \\
\hline Control & 298 & 2 & 300 \\
Center & 435 & 165 & 600 \\
Edge & 43 & 557 & 600 \\
Total & 776 & 724 & 1500 \\
& \multicolumn{3}{c}{$G=1038.3, \mathrm{df}=2, \mathrm{p}<0.05$} \\
\hline
\end{tabular}

the large disease-surviving patches (Fig. 5). There was a strong and significant dependence between the number of mesenteries bearing eggs and the size of the patches $(G=3164.8, \mathrm{df}=2, \mathrm{p}<0.05)$ and the tissue location (edge, center) within the patches $(G=1038.3$, $\mathrm{df}=2, \mathrm{p}<0.05$; Tables $2 \& 3$ ).

Field observations of the spawning behavior of healthy and YBD-infected colonies were consistent with the histological observations. All observed healthy colonies of Montastraea faveolata were ready to spawn by $21: 30$ to $22: 15 \mathrm{~h}$ during the seventh night after the full moon of August 2005. Spawning of healthy colonies occurred between 21:45 and 22:15 h, and depending on colony size, it took between 20 and 35 min to complete. YBD-infected tissues did not show any spawning behavior and did not spawn in any of the monitored diseased colonies, and only a few bundles were released from the TR tissues. The areas of healthy-looking tissues of diseased colonies spawned, but no significant qualitative differences could be observed with $\mathrm{CO}$ colonies. From the histology slides, it could be inferred that HD gamete bundles probably had significantly lower numbers of eggs than $\mathrm{CO}$ bundles. All small patches $\left(<100 \mathrm{~cm}^{2}\right)$ and smaller colonies observed did not spawn or show any spawning behavior, whereas larger patches (400 to $1000 \mathrm{~cm}^{2}$ ) spawned in synchrony with the large colonies.

\section{DISCUSSION}

Quantitative and qualitative results of this study indicate that YBD could affect the reproductive output of Montastraea faveolata by at least 5 mechanisms: (1) loss of reproductive polyps by disease-induced tissue mortality, (2) significant reduction in fecundity in disease lesions and nearby transition areas with a potential systemic effect over the entire colony, (3) reduction of live-tissue areas below the size threshold for sexual reproduction (small patches), (4) reduction in fecundity by increases in the 'edge effect' produced by partial mortality, and (5) reduction in energy production in the pale, yellowish zooxanthellae-depleted areas. Furthermore, if YBD-infected colonies have compromised immune systems, they would be more susceptible to other infections that could further develop into multiple diseases affecting a single colony, already observed in several localities around the Caribbean (Cróquer \& Weil 2009a, Weil \& Cróquer 2009), which could further reduce fecundity.

Pathogens represent a strong selective force for wildlife populations as they affect individual fitness by reducing the reproductive output of infected hosts (Alker et al. 2001). While the effects of pathogens on the reproductive output of wildlife populations of ter- 
restrial animals have been well studied (Gulland 1995), in corals, this problem remains poorly understood (Petes et al. 2003, Flynn \& Weil in press). Our results indicated a significant reduction in fecundity of Montastraea faveolata infected with YBD, which affects their fitness, with potential detrimental consequences to population dynamics and reef recovery. Sexual reproduction failure in anthozoans has been associated with many sources of stress including those mentioned above (turbidity/sedimentation, eutrophication, mechanical stress, oil and chemical pollution, bleaching, UV radiation), and recently, as shown in this study, biotic diseases play an important role.

While previous spawning observations have shown healthy-looking tissues in colonies with YBD-releasing bundles (Bastidas et al. 2005), results of the present study provide the first quantitative evidence of infertility in polyps affected by the disease, and a significant reduction in fecundity in polyps close to the lesion. Although no significant differences were found, the trend observed indicated that YBD might have a systemic effect, affecting healthy-looking tissues far from the active lesions in infected colonies. This systemic effect might be more evident in colonies with multiple lesions. Reduction in fecundity could result from significant depletion of energy resources (e.g. redirected for other physiological needs such as immune responses) that might affect energy budgets in infected hosts. Corals receive more than $80 \%$ of their energy requirements from photosynthesis (Muscatine 1990), and because YBD-infected tissues have low densities of zooxanthellae (Cervino et al. 2001, 2004), less energy for reproduction is available. Moreover, energy could be translocated into affected tissues from healthy areas; however, if the whole colony is compromised and resources have been diverted (immune and defense responses or new asexual reproduction and tissue repair), output by sexual reproduction may ultimately be affected.

Normally, corals distribute their energy into 3 main processes: (1) growth (which includes tissue regeneration), (2) maintenance (respiration, feeding, defense) and (3) reproduction (production of male and female gametes, spawning) with each competing for the coral's resources (Harrison \& Wallace 1990). The patterns of stress response in corals indicate that resource allocation to various life functions is hierarchical, with maintenance, repair, and growth preceding sexual reproduction in many situations (Harrison \& Wallace 1990). Tissue regeneration frequently proceeds at the expense of sexual reproduction in sponges and corals. Regenerating individuals often reduce fecundity and remain sexually infertile or may prematurely shed nonviable sexually-derived larvae (Richmond 1987,
Van Veghel \& Bak 1994, Rinkevich 1996, Henry \& Hart 2005). In cases where energy does not seem to be limiting, sexual reproduction may also be suppressed following regeneration due to the exhaustion of stem cell resources that are used in gamete production and regeneration. Recent studies have shown that translocation of ${ }^{14} \mathrm{C}$ labeled photo-assimilates is preferentially directed away from diseased tissues, with minimal ${ }^{14} \mathrm{C}$ activity observed in the lesion borders (Roff et al. 2006).

Preferential movement of photo-assimilates away from diseased tissues may represent a 'deliberate' strategy by the colony to induce a 'shutdown reaction' in order to preserve intra-colonial resources within areas of the colony that are more likely to survive and recover (Roff et al. 2006). Although untangling the mechanisms by which fecundity is reduced goes far beyond the scope of this study, energy reallocation might explain the 50 and $27 \%$ fecundity reduction in transition and healthy-looking tissues in diseased colonies, respectively.

The high concentration of lipids in oocytes could be a source of energy when resources are depleted. Oocyte re-absorption (Szmant-Froelich et al. 1980) could then provide energy in resource-limited diseased tissues/colonies. In Diploria strigosa, for example, up to $30 \%$ of oocytes may degenerate and be reabsorbed (Harrison \& Wallace 1990). Endolithic algae might be another source of energy in diseased colonies by re-allocating photo-assimilates for tissue repair or defense mechanisms (Fine \& Loya 2004). We observed higher biomass of algae in skeletal areas underneath the partially bleached YBD-infected tissues after decalcification, so it is possible that affected tissue remains alive longer due to photo-assimilate translocation from these algae.

Fragmentation has negative effects on the reproductive output of scleractinians (Kojis \& Quinn 1981, 1984, Szmart-Froelich 1985, Harrison \& Wallace 1990). Results of this study showed that the effect of YBD on reproduction in Montastraea faveolata persists even after the infections have arrested. Fecundity of previously infected colonies remained significantly low compared to healthy control corals due to the disruption of tissue continuity and a concomitant extension of the 'border effect' in the new-formed edges of the surviving patches. Our results showed that large and small patches of living tissues had a 64 and $84 \%$ reduction in fecundity, respectively, compared to control corals and that edges had significantly lower fecundity than central areas in the sample patches.

Corals distribute their reproductive effort in a spatial gradient, with more fecundity concentrated towards the center of the colonies and absence of gametes in their edge areas (Harrison \& Wallace 1990), where 
energy and resources are used for modular growth and regeneration rather than for sexual reproduction (Szmant-Froelich et al. 1980, Szmant-Froelich 1985, Henry \& Hart 2005). Furthermore, scleractinian corals have a variable minimum sexual reproductive size, depending on the species. Colonies of Montastraea faveolata do not sexually reproduce until they are larger than 100 to $110 \mathrm{~cm}^{2}$ (Szmant-Froelich 1985). Thus, YBD not only compromises fecundity in tissues of diseased colonies, but also reduces living areas below the minimum size for sexual reproduction and increases the border effect through partial mortality. This was supported by the significant positive correlation found between fecundity and size of patches, lower number of gravid mesenteries in the tissues bordering living patches, and field observations of spawning.

Lower numbers of gamete bundles and/or bundles with fewer eggs would affect fertilization success and production of new larvae (Harrison \& Wallace 1990, Hughes et al. 2000), and eventually, the effective number of new recruits incorporated into the population. Recruitment failure has been highlighted as one of the major factors challenging the resilience of coral reefs (Bellwood et al. 2003, 2004, Hughes et al. 2003). Edmunds (1991) found low recruitment onto bare skeletons recently exposed due to partial mortality produced by black band disease. Thus, while coral diseases act as a 'natural disturbance' opening space for new recruits, overall recruitment is probably decreasing because diseases and other stressors are reducing the fecundity of adult colonies. The extensive bare areas left by disease-induced mortality of Montastraea faveolata and $M$. annularis colonies due to YBD, white plague (WP-II), and bleaching in recent years will serve as natural experimental areas to test this hypothesis.

As a strong selective force on susceptible taxa, and because they are affecting not only major coral species but several other important reef organisms as well (Weil 2004, Weil et al. 2006), diseases of coral reef organisms might have long-term and evolutionary consequences on the structure and dynamics of individual species and coral reef communities and ecosystems. After the regional decline of acroporids, the Montastraea species complex has remained as the most important reef-building corals in the Caribbean, with high abundances and cover, large and structurally complex colonies, and extensive geographic and depth distribution patterns (Weil \& Knowlton 1994).

However, the 3 species in the Montastraea annularis species complex and $M$. cavernosa, which are important and abundant reef-builders, are also highly susceptible to 7 other biotic diseases and to bleaching
(Weil 2004, McClanahan et al. 2009). Of these, WP-II is a highly virulent disease with frequent outbreaks in recent years producing significant mortalities in several localities around the Caribbean (Richardson 1998, Weil et al. 2002, Miller et al. 2006). High partial tissue mortalities due to bleaching were observed for the first time during the strong 2005 event in several localities (Miller et al. 2006, Cróquer \& Weil 2009b, this Special), adding to the already depleted fecundity in this species. Furthermore, bleaching reduces fecundity (Szmant \& Gassman 1990, Mendes \& Woodley 2002a,b); thus, surviving tissues undergo reproductive failure after a strong bleaching event, as observed in 2006, when M. faveolata colonies in Puerto Rico produced very few bundles, which were non-viable in laboratory cultures (E. Weil et al. unpubl. data).

Recently, Carpenter et al. (2008) indicated that declines in abundance of scleractinian coral species around the world seem to be mostly associated with bleaching and diseases driven by elevated sea surface temperatures, with their extinction risk further exacerbated by local-scale anthropogenic disturbances. Results of this and other studies have shown that diseases and bleaching significantly reduce the fitness of major reef-building species, thereby affecting the potential for natural recovery of their populations by sexual recruits. If we add all other environmental and anthropogenic stressors that reduce not only fecundity, but fertilization success, recruitment, and juvenile and adult survivorship, the future of important reef-building species as major structural and biological components of Caribbean coral reefs might be in jeopardy. The current widespread YBD epizootic affecting the Montastraea spp. complex (Cróquer \& Weil 2009a) could potentially produce a second Caribbean-wide coral community phase-shift, with many reefs experiencing significant losses in live coral cover and changes in their structure and composition with uncertain short and long-term (evolutionary) consequences at the population, community, and ecosystem levels.

In conclusion, YBD and potentially other coral diseases can affect the fitness of major species of corals by loss of reproductive polyps, reduction of fecundity in transition areas and systemic effects of the disease, increasing the 'edge effect' within colonies, and the fractionation of tissue continuity producing small patches of live tissue within colonies, among other mechanism that reduce fecundity and therefore affect overall fitness. As diseases are becoming more prevalent in reefs around the world, fitness of susceptible coral species could be significantly reduced by disease-induced mortality and physiological and/or systemic effects with negative implications for population dynamics and coral reef recovery. 
Acknowledgements. Funding for this study was provided by the GEF-World-Bank Coral Reef Targeted Research and Capacity Building program through the Disease Working Group. Partial funding was provided by the NOAA-CRES project (NA170P2919) and the UPRM SeaGrant Program Grant (\#R-101-1-99) to E.W. Logistical support was provided by the Department of Marine Sciences, UPRM. We thank C. Bastidas, K. Flynn, S. Williams, and 2 anonymous reviewers for their valuable comments, which improved this manuscript.

\section{LITERATURE CITED}

Alker AP, Smith GW, Kim K (2001) Characterization of Aspergillus sidowii (Thom et Church), a fungal pathogen of Caribbean sea fans. Hydrobiologia 460:105-111

Alker AP, Kim K, Dube DH, Harvell CD (2004) Localized induction of a generalized response against multiple biotic agents in Caribbean sea fans. Coral Reefs 23: 397-405

> Altizer AP, Harvell DC, Friedle E (2003) Rapid evolutionary dynamics and disease threats to biodiversity. Trends Ecol Evol 18:589-596

Aronson RB, Precht WF (2001) White-band diseases and the changing face of Caribbean coral reefs. Hydrobiologia 460:25-38

Bassim KM, Sammarco PW (2003) Effects of temperature and ammonium on larval development and survivorship in a scleractinian coral (Diploria strigosa). Mar Biol 142: 241-252

Bastidas C, Cróquer A, Zubillaga AL, Ramos R, Kortnik V, Weinberger C, Márquez LM (2005) Coral mass- and splitspawning at a coastal and an offshore Venezuelan reefs, southern Caribbean. Hydrobiologia 541:101-106

Bellwood DR, Hoey AS, Choat J (2003) Limited functional redundancy in high diversity systems: resilience and ecosystem function in coral reefs. Ecol Lett 6:281-285

Bellwood DR, Hughes TP, Folke C, Nystrom M (2004) Confronting the coral reef crisis. Nature 429:827-833

Bongiorni L, Shafir S, Angel D, Rinkevich B (2003) Survival, growth and gonad development of two hermatypic corals subjected to in situ fish-farm nutrient enrichment. Mar Ecol Prog Ser 253:137-154

Borger JL, Steiner SCC (2005) The spatial and temporal dynamics of coral diseases in Dominica, West Indies. Bull Mar Sci 77:137-154

Bruckner AW, Bruckner RJ (2006) Consequences of YBD on Montastraea annularis (species complex) populations on remote reefs off Mona Island, Puerto Rico. Dis Aquat Org 69:67-73

Bruno JF, Peters LE, Harvell CD, Hettinger A (2003) Nutrient enrichment can increase the severity of coral diseases. Ecol Lett 6:1056-1061

Carpenter KE, Abrar M, Aeby G, Aronson RB and others (2008). One-third of reef-building corals face elevated extinction risk from climate change and local impacts. Science 321:560-563

Cervino J, Goreau TJ, Nagelkerken I, Smith GW, Hayes R (2001) Yellow band and dark spot syndromes in Caribbean corals: distribution, rate of spread, cytology, and effects on abundance and division rate of zooxanthellae. Hydrobiologia 460:53-63

Cervino JM, Hayes LH, Polson SW, Polson SC, Goreau TJ, Martinez RJ, Smith GW (2004) Relationship of Vibrio species infection and elevated temperatures to yellow blotch/band disease in Caribbean corals. Appl Environ Microbiol 70:6855-6864
Cervino JM, Thompson FL, Gómez-Gil B, Lorence EA and others (2008) Vibrio pathogens induce yellow band disease in Caribbean and Indo-Pacific reef-building corals. J Appl Microbiol 105:1658-1671

Cróquer A, Weil E (2009a) Spatial variability in distribution and prevalence of Caribbean scleractinian coral and octocoral diseases. II. Genera-level analysis. Dis Aquat Org 83:209-222

Cróquer A, Weil E (2009b) Changes in Caribbean coral disease prevalence after the 2005 bleaching event. Dis Aquat Org 87:33-43

> Daszak P, Cunningham AA, Hyatt AD (2000) Emerging infectious diseases of wildlife threats to biodiversity and human health. Science 287:443-449

Deredec A, Courchamp F (2003) Extinction thresholds in hostparasite dynamics. Ann Zool Fenn 40:115-130

Edmunds PJ (1991) Extent and effect of black band disease on a Caribbean reef. Coral Reefs 10:161-165

Edmunds PJ (2005) Effects of elevated temperature on aerobic respiration of coral recruits. Mar Biol 146:655-663

Fine M, Loya Y (2004) Coral bleaching in a temperate sea: from colony physiology to population ecology. In: Rosenberg E, Loya Y (eds) Coral health and disease. SpringerVerlag, Berlin, p 143-155

Flynn K, Weil E (in press) Prevalence, distribution and virulence of aspergillosis affecting Gorgonia ventalina in La Parguera, Puerto Rico. Caribb J Sci

Gil-Agudelo DL, Smith GW, Garzón-Ferreira J, Weil E, Peterson D (2004) Dark spots disease and yellow band disease, two poorly known diseases with high incidence in Caribbean reefs. In: Rosenberg E, Loya Y (eds) Coral health and disease. Springer-Verlag, Berlin, p 337-350

Gladfelter WB (1982) White-band disease in Acropora palmata: implications for the structure and growth of shallow reefs. Bull Mar Sci 32:639-643

Gulland FMD (1995) The impact of infectious diseases on wild animal populations - a review. In: Grenfell BT, Dobson AP (eds) Ecology of infectious diseases in natural populations. Cambridge University Press, Cambridge, p 20-51

Guzmán HM, Holst I (1993) Effects of chronic oil-sediment pollution on the reproduction of the Caribbean reef coral Siderastrea siderea. Mar Pollut Bull 26:276-282

Harrison P, Wallace CC (1990) Reproduction, dispersal and recruitment of scleractinian corals. In: Dubinsky Z (ed) Ecosystems of the world, Vol 25-Coral reefs. Elsevier, New York, p 133-207

Harvell D, Markel S, Jordan-Dahlgren E, Raymundo L and others (2007) Coral disease, environmental drivers and the balance between coral and microbial associates. Oceanography 20:36-59

Harvell D, Altizer S, Cattadori IM, Harrington L, Weil E (2009) Climate change and wildlife diseases: When does the host matter the most? Ecology 90:912-920

Henry LA, Hart M (2005) Regeneration from injury and resource allocation in sponges and corals - a review. Int Rev Hydrobiol 90:125-158

> Hilbish TJ (1996) Population genetics of marine species: the interaction of natural selection and historically differentiated populations. J Exp Mar Biol Ecol 200:67-83

Hughes TP, Connell JH (1999) Multiple stressors on coral reefs: a long-term perspective. Limnol Oceanogr 44: 932-940

Hughes TP, Tanner JE (2000) Recruitment failure, life histories, and long-term decline of Caribbean corals. Ecology 81:2250-2263

Hughes TP, Baird AH, Dinsdale EA, Motschaniwskyj NA, Pratchett MS, Tanner JE, Willis BL (2000) Supply-side 
ecology works both ways: the link between benthic adults, fecundity, and larval recruits. Ecology 81: 2241-2249

Hughes TP, Baird AH, Bellwood DR, Card M and others (2003) Climate change, human impacts and the resilience of coral reefs. Science 301:929-933

Knowlton N, Weil E, Weigt LA, Guzman HM (1992) Sibling species in Montastraea annularis, coral bleaching, and the coral climate record. Science 255:330-333

Kojis BL, Quinn NJ (1981) Aspects of sexual reproduction and larval development in the shallow water hermatypic coral Goniastrea australensis (Edwards and Haime, 1857). Bull Mar Sci 31:558-573

Kojis BL, Quinn NJ (1984) Seasonal variation in fecundity of Acropora palifera at two reefs in Papua New Guinea. Coral Reefs 3:165-172

Lessios HA, Robertson DR, Cubit JD (1984) Spread of Diadema mass mortality throughout the Caribbean. Science 226:335-337

McClanahan TR, Weil E, Cortés J, Baird A, Ateweberhan M (2009) Consequences of coral bleaching for sessile organisms. In: van Oppen M, Lough J (eds) Coral bleaching: patterns, processes, causes and consequences. Springer Ecological Studies, Berlin, p 121-138

Mendes JM, Woodley JD (2002a) Timing of reproduction in Montastraea annularis: relationship to environmental variables. Mar Ecol Prog Ser 227:241-251

Mendes JM, Woodley JD (2002b) Effect of the 1995-1996 bleaching event on polyp tissue depth, growth, reproduction and skeletal band formation in Montastraea annularis. Mar Ecol Prog Ser 235:93-102

> Metz JAJ, Nisbet RM, Geritz SAH (1992) How should we define fitness for general ecological scenarios? Trends Ecol Evol 7:198-202

Miller J, Waara R, Muller E, Rogers C (2006) Coral bleaching and disease combine to cause extensive mortality on corals reefs in US Virgin Islands. Coral Reefs 25:418

Muscatine L (1990) The role of symbiotic algae in carbon and energy flux in reef corals. Coral Reefs 25:1-29

- Nugues MM (2002) Impact of a coral disease outbreak on coral communities in St Lucia: What and how much has been lost? Mar Ecol Prog Ser 229:61-71

Petes LE, Harvell CD, Peters EC, Webb MAH, Mullen KM (2003) Pathogens compromise reproduction and induce melanization in Caribbean sea fans. Mar Ecol Prog Ser 264:167-171

Richardson LL (1998) Coral diseases: What is really known? Trends Ecol Evol 13:438-443

Richmond RH (1987) Energetic relationships and biogeographical differences among fecundity, growth and reproduction in the reef coral Pocillopora damicornis. Bull Mar Sci 41:594-604

Rinkevich B (1996) Do reproduction and regeneration in damaged corals compete for energy allocation? Mar Ecol Prog Ser 143:297-302

Roff G, Hoegh-Guldberg O, Fine M (2006) Intra-colonial response to acroporid 'white syndrome' lesions in tabular Acropora spp (Scleractinia). Coral Reefs 25:255-264

Rogers CS, Miller J (2006) Permanent 'phase shifts' or reversible declines in coral cover? Lack of recovery of two coral reefs in St. John, US Virgin Islands. Mar Ecol Prog Ser 306:103-114

Saccheri I, Hanski I (2006) Natural selection and population dynamics. Trends Ecol Evol 21:341-347

Santavy DL, Peters EC, Quirolo C, Porter JW, Bianchi CN (1999) Yellow-blotch disease outbreak on reefs of the San Blas Islands, Panama. Coral Reefs 18:97
Sokal RR, Rohlf FJ (1995) Biometry the principles and practice of statistics in biological research. WH Freeman and Company, New York

Sutherland KP, Porter JW, Torres C (2004) Disease and immunity in Caribbean and Indo-Pacific zooxanthellate corals. Mar Ecol Prog Ser 266:273-302

Szmant AM (1986) Reproductive ecology of Caribbean reef corals. Coral Reefs 5:43-54

Szmant AM, Gassman NJ (1990) The effects of prolonged 'bleaching' on the tissue biomass and reproduction of the reef coral Montastrea annularis. Coral Reefs 8:217-224

Szmant-Froelich A (1985) The effect of colony size on the reproductive ability of the Caribbean coral Montastraea annularis (Ellis and Solander). Proc 5th Int Coral Reef Congress Tahiti 4:295-300

> Szmant-Froelich A, Yevich P, Pilson MEQ (1980) Gametogenesis and early development of the temperate coral Astrangia danae (Anthozoa: Scleractinia). Biol Bull (Woods Hole) 158:257-269

Tanner JE (1997) Interspecific competition reduces fitness in scleractinian corals. J Exp Mar Biol Ecol 214:19-34

Torres JL, Armstrong RA, Weil E (2008) Enhanced ultraviolet radiation can terminate sexual reproduction in the broadcasting coral species Acropora cervicornis Lamarck. J Exp Mar Biol Ecol 358:39-45

Van Oppen MJH, Willis BL, Van Rheede T, Miller DJ (2002) Spawning times, reproductive capabilities and genetic structuring in the Acropora aspera group: evidence from natural hybridization and semi-permeable species boundaries in corals. Mol Ecol 11:1363-1376

> Van Veghel MLJ, Bak RPM (1994) Reproductive characteristics of the polymorphic Caribbean reef-building coral Montastrea annularis. III. Reproduction in damaged and regenerating colonies. Mar Ecol Prog Ser 109:229-233

Vermeij MJA (2005) Substrate composition and adult distribution determine recruitment patterns in a Caribbean brooding coral. Mar Ecol Prog Ser 295:123-133

Vermeij MJA (2006) Early life-history dynamics of Caribbean coral species on artificial substratum: the importance of competition, growth and variation in life-history strategy. Coral Reefs 25:59-71

Vermeij MJA, Sampayo E, Bröker K, Bak RPM (2003) Variation in planulae release of closely related coral species. Mar Ecol Prog Ser 247:75-78

Ward S (1995) The effect of damage on the growth, reproduction and lipid storage in the scleractinian coral Pocillopora damicornis. J Exp Mar Biol Ecol 187:193-206

Ward S, Harrison PL (1997) The effects of elevated nutrients on settlement of coral larvae during the ENCORE experiment. Proc 8th Int Coral Reef Symp Panama 1:891-986

Ward S, Harrison PL (2000) Changes in gametogenesis and fecundity of acroporid corals that were exposed to elevated nitrogen and phosphorus during the ENCORE experiment. J Exp Mar Biol Ecol 246:179-221

Ward S, Harrison PL, Hoegh-Guldberg O (2000) Coral bleaching reduces reproduction on scleractinian corals and increases susceptibility for future stress. Proc 9th Int Coral Reef Symp Bali 2:1123-1128

Weil E (2004) Coral reef diseases in the wider Caribbean. In: Rosenberg E, Loya Y (eds) Coral health and disease. Springer-Verlag, Berlin, p 35-67

- Weil E, Cróquer A (2009) Spatial variability in distribution and prevalence of Caribbean scleractinian coral and octocoral diseases. I. Community-level analysis. Dis Aquat Org 83:195-208

Weil E, Knowlton N (1994) A multi-character analysis of the Caribbean coral Montastraea annularis (Ellis \& Solander 
1786) and its two sibling species M. faveolata (Ellis \& Solander 1786) and M. franksi (Gregory 1895). Bull Mar Sci 55:151-175

Weil E, Urreiztieta I, Garzón-Ferreira J (2002) Geographic variability in the incidence of coral and octocoral diseases in the wider Caribbean. Proc 9th Int Coral Reef Symp Bali 2:1231-1237

Weil E, Smith GW, Gil-Agudelo DL (2006) Status and progress

Editorial responsibility: Kiho Kim,

Washington, DC, USA in coral reef disease research. Dis Aquat Org 69:1-7

Weil E, Ritchie KB, Croquer A, Smith GW (in press) Inoculation of Vibrio spp. onto Montastraea faveolata fragments to determine potential pathogenicity. Proc 11th Int Coral Reef Symp Ft. Lauderdale, FL

Willis BL, Page CA, Dinsdale EA (2004) Coral disease in the Great Barrier Reef. In: Rosenberg E, Loya Y (eds) Coral health and disease. Springer-Verlag, Berlin, p 69-102

Submitted: January 19, 2008; Accepted: June 22, 2009

Proofs received from author(s): September 18, 2009 